\title{
A Park to Save the Arabian Tahr
}

\section{David L. Harrison and Michael D. Gallagher}

There is at present no national park in any part of peninsular Arabia. The FPS therefore welcomed the chance to help Dr Harrison and Major Gallagher formulate their plans for a park in Oman to help save the Arabian tahr and also pioneer the idea of national parks in the Arab world. The FPS approached the Omani authorities, who readily agreed to allow Major Gallagher to make the preliminary survey, and the Society is also sponsoring the proposed scientific expedition in April 1975 described in this article. Michael Gallagher's photograph above was taken in the area.

A species of unique interest, the Arabian tahr Hemitragus jayakari is one of the rather few indigenous Arabian mammals. It is confined entirely to the mountains of Oman, and is one of the smallest living wild goats. Described by Oldfield Thomas $(18941,2)$, it was named in honour of its discoverer, Dr A. S. G. Jayakar, who contributed so much to our knowledge of the mammals of Oman. Today its only living relatives are the Himalayan tahr $H$. jemlahicus, found in the Himalayas from Kashmir to Sikkim, and the Nilgiri tahr H. hylocrius, in the Nilgiri Hills of southern India. Fossil evidence shows tahr species in Europe during the middle and late Pleistocene, so that these isolated surviving species may be regarded as relicts of a former more widely distributed stock.

The Arabian tahr is a most distinctive animal. Much smaller than the other species, both living and fossil, it stands about $24 \frac{1}{2}$ inches at 


\section{LOCAL INHABITANTS}

the withers and is only about $37 \frac{1}{2}$ inches in total length (Harrison 1968). The males are beardless, with short, laterally compressed horns and well marked blackish spinal crest and facial striation. The pelage is notably coarse and shaggy in winter, forming pronounced tufts on the angles of the lower jaw and 'ruffs' on the legs. Females have rather smaller horns and less well-defined markings. Very little is known about its habits and biology.

In recent years there has been increasing concern for the future of this tahr, having regard to its limited habitat and the country's rapid development. Reports suggested a marked diminution in the Jebel Akhdar population, and the species may be in danger of early extinction.

In the spring of 1973 the authors formulated a plan for a national park in the Jebel Akhdar Range. HM the Sultan of Oman has expressed his interest in the possibility of developing such a park, and has authorised the necessary preliminary surveys. The area we provisionally selected is almost rectangular, about $50 \mathrm{~km}$ across and $30 \mathrm{~km}$ from north to south, in the Hajar al Gharbi (Western Mountains) just south of Rostaq. It includes the main massif of the Jebel el Akhdar (Green Mountain) rising to $2980 \mathrm{~m}$. and some of Oman's most spectacular scenery.

A week's preliminary survey made by M.D.G. with a party of nine soldiers in March 1973 was most encouraging, suggesting that the area would be generally suitable, with Rostaq as the park's administrative base and tourist centre. But the scarcity of tahr in the area disclosed by the survey party confirms the urgent need for action, although it is extremely difficult to assess the actual size of the population in such inaccessible terrain.

We are now planning a more detailed scientific survey expedition, not only to find out more about the tahr's status but also to investigate the general fauna and flora and consider the integration of the resident mountain tribesmen into the park plan. Recent reports suggest a fair population of tahr in the Jebel Aswad-Jebel Abyadh, in the Hajar ash Sharqi area, and this region should also be investigated as a possible tahr reserve. 
ORPHANED

ARABIAN TAHR

David Insall

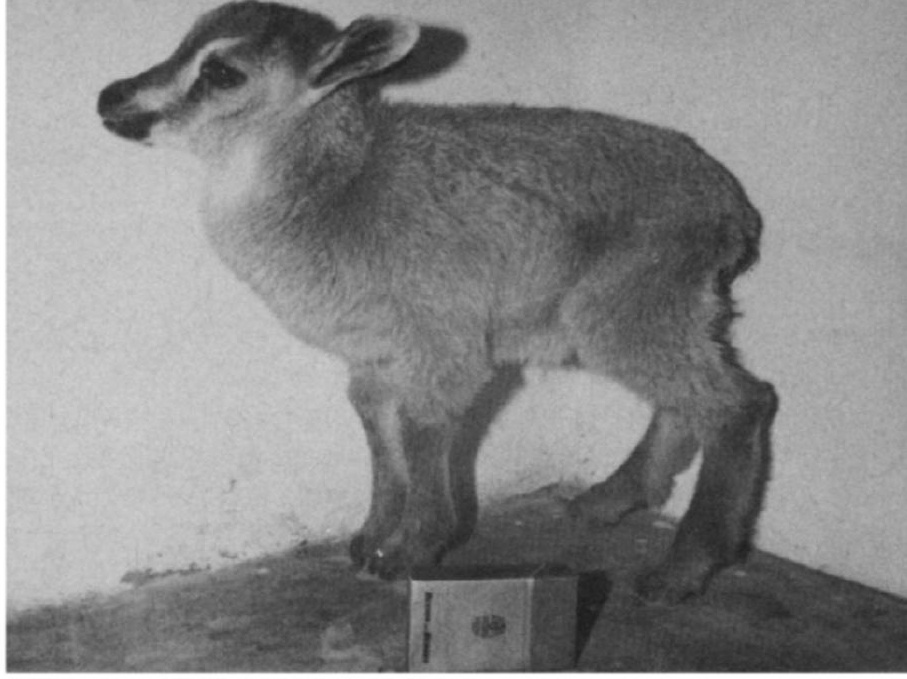

Plans are now in hand for a survey party of six people, including the authors, to make these more detailed studies in April 1975. After that we hope to prepare a detailed feasibility report on the Project and submit concrete recommendations to the Sultan's Government.

\section{References}

HARRISON, D.L., 1968. The Mammals of Arabia, Vol II. Carnivora. Artiodactyla. Hyracoidea. Benn, London. pp. 193-380.

THOMAS, O., 1894 (1). Preliminary Description of a new Goat of the Genus Hemitragus from South-eastern Arabia. Ann. Mag. Nat. Hist. 13:365.

THOMAS, O., 1894 (2). On some specimens of Mammals from Oman, S.E. Arabia. P.Z.S.: 452 .

\section{FPS Consultants}

Two names have been added to the Society's Overseas Consultants: Afghanistan: Dr Ronald Petocz

Fiji: Mr E. J. H. Berwick

The Society now has 97 correspondents in 66 countries: see Oryx October 1973, page 184; February 1974, 307; and June 1974, 412.

\section{Two more prizes}

In addition to the J. Paul Getty Prize (Oryx May, page 418) there are now two annual environmental prizes. The Pahlavi Environmental Prize is given by the Government of Iran 'to further reaffirm its interest in the international effort for the improvement of the human environment'. The sum of $\$ 20,000$ will be placed each year at the disposal of the Secretary-General of the United Nations for 'the most outstanding contribution' in this field each year. The Tyler Ecology Award, established by the late John C. Tyler, is to be of $\$ 150,000$, for 'the person or group who has conferred the greatest benefit to mankind in the field of ecology and improvement of the environment'. The Executive Secretary of the Selection Committee (entries by October 1 each year) is George C. Bales, Pepperdine University, 24255 Pacific Coast Highway, Malibu, California 90265, USA. 